\title{
Political Connections, Financing and Dividend Policy
}

\author{
Leonita Putri ${ }^{1,2, *}$ \\ ${ }^{1}$ FEB Faculty \\ ${ }^{1}$ Padjadjaran University, ${ }^{2}$ Sriwijaya University \\ ${ }^{1}$ Bandung, Indonesia, ${ }^{2}$ Palembang, Indonesia \\ *leonita_putri51@yahoo.com
}

\author{
Sulaeman Rahman Nidar, Rachmat Sudarsono \\ FEB \\ Padjadjaran University \\ Bandung, Indonesia \\ sulaeman.rahman@unpad.ac.id, \\ rachmat.sudarsono@fe.unpad.ac.id
}

\author{
Josep Ginting \\ President University \\ Cikarang, Indonesia \\ josepginting@president.ac.id
}

\begin{abstract}
The purpose of this study is to see the political connections DER, EPS, SIZE, growth and ROA influence on the company's dividend distribution policy. The sample in the study SOE listed on the Indonesia Stock Exchange in 2010-2018 period. The sample was selected using purposive sampling technique and obtained 12 companies. This study uses a quantitative approach with analysis tools using multiple linear regression with the help of EViews 9.0 software. The results of this study indicate that political connections, Capital structure, Growth have a negative effect on dividend policy and size, EPS, ROA have a positive effect on dividend policy.
\end{abstract}

Keywords—political, capital structure, dividend

\section{INTRODUCTION}

SOE is a business entity which all or most of its capital is owned by the state through direct investment originating from the incoming state assets (Law No. 19 of 2003). Several forms of SOE business, but the samples in the research of SOEs in the form of PT or Limited Liability Companies listed on the Indonesia Stock Exchange (IDX) from 2010 to 2018 will be formed into two parts, namely SOE Manufacturing and Service SOE. In investing their capital, investors will carefully consider which companies the capital will be invested in. Because in general, the main objective of investors in investing their funds in the company is to seek income or the rate of return on investment (return), one of which is dividend income [1]. Management investors often have different interests. Management tends to prioritize personal interests; which investors do not like. Dividend policy is one of the important decisions for the company, because the policy is related to the company's decision to determine the amount of net income to be distributed as dividends and how much profit is reinvested in the company in the form of retained earnings. Dividend policy is also an important part of the company's long-term funding strategy in responding to environmental dynamics [2].
In 2017, several SOE were not able to pay dividends because they were still facing bad finances. Minister of Finance Sri Mulyani revealed that up to semester 1, 2017, from 118 SOEs, dividend payments of IDR 32 trillion and taxes of IDR 97 trillion had been obtained, or a total of IDR 129 trillion. Meanwhile, net profit reached Rp. 87 trillion with total assets of Rp. 6,694 trillion. However, there are still some SOEs that are losing money and cannot pay dividends. She said, several SOEs that have not been able to pay dividends due to lack of business competition and efficiency are Garuda Indonesia, PT PAL, Krakatau Steel, Bulog, and Balai Pustaka. He explained that the number of paid dividends is adjusted to financial flows, solvency, liquidity, and other financial ratios. Sri Mulyani explained that SOE companies in paying dividends are categorized into three payout ratios, namely low, medium, or in the range of $0-50 \%$. SOE with a low payout ratio or below $20 \%$ are SOE whose business sector is dedicated to providing social service security, including old age insurance and the environment such as Taspen, Asabri, and Perhutani. Activities in SOE management basically apply the principle of agency theory, because there is a separation of ownership between owners and management in managing SOE operations.

SOE management is delegated by the trustee (in this case the people as the ultimate owner) believes that the trustee (the government through its representatives in the management as the actual owner) has adequate capacity to carry out the delegated mandate. In practice, conflicts of interest often occur in the management of SOEs, reflected in the decision making and decision making related to investment activities, funding and dividend policy. Aims of this research are:

- EPS effect on Dividend Payout Ratio

- Political Connections effect on Dividend Payout Ratio

- Size effect on Dividend Payout Ratio

- Growth effect on Dividend Payout Ratio 
- Capital Structure effect on Dividend Payout Ratio

- Profitability effect on Dividend Payout Ratio

\section{LITERATURE REVIEW}

Gupta and Banga [3] show leverage and liquidity are determinants of dividend policy for Indian companies. Gill et al., [4] sales growth and debt to equity ratio are the main determinants of dividend policy in service companies. Kapoor et al., [5] stated that dividend payments are positively related to earnings, temporary cash flow, capex, retained earnings, sales growth, stock prices, beta, interest paid and debt equity ratios have an inverse relationship.

Islam et al., [6] stated that if the PE ratio, EPS growth and sales growth were positively related to dividend payments, profitability and debt to equity were found to have a negative relationship with dividend payments. Singhania and Gupta [7], research shows that company size (market capitalization) and company growth and investment opportunities are significant determinants of corporate dividend policy in India. Profitability, debt structure and experience do not represent significant determinants of the Indian scenario.

Earning per share is the first important component that must be considered in a company analysis. Earning per share information of a company shows the amount of the company's net profit that is ready to be distributed to all shareholders of the company. Based on the theory from the results of previous research regarding the relationship of earnings per share to dividend policy, Earnings Per Share (EPS) has a significant positive effect. and significant to the Dividend Policy [8-11]

Zameer et al., [12] identified the determinants of dividend policy in the Pakistani banking sector. Coverage is limited to the 2003-2009 period. A stepwise regression analysis was performed. This study found that profitability, last year's dividend and ownership structure showed a positive impact on dividend payments and liquidity showed a negative impact on the banking industry. No significant relationships were found with size, leverage, agency costs, growth and risk.

Fisman [13] examines the political connections in Indonesia that link information about the health rumors of Suharto, the President of Indonesia, with company value. Fisman [13] found that stock price movements are related to Suharto's health information for companies that are politically connected compared to companies that are not politically connected, so share price reactions are worse when they get negative news. while Johnson and Mitton [14] suggest that companies that are politically linked with Prime Minister Mahathir Mohamad in Malaysia have significantly higher stock returns.

The dividend policy adopted by the company is influenced by several things. Baker and Powell [15] state that the level of future income is one of the determinants of dividend distribution. Then, Roberto [16] also states that investment opportunities are one of the factors that influence the company's dividend policy. Investment opportunities are closely related to the network owned by the company. One thing that can strengthen a company's business network is the existence of political connections with the authorities.

\section{METHODS}

This type of research is inductive research, using exploratory models while the data analysis technique used is statistical analysis. This research is using panel data with the Random Effect analysis model and solved through computer statistics, namely Eviews 9.0. The data used in this study are secondary data, from 2010 to 2018. Data criteria are:

- Companies registered from 2010 to 2018

- Paying Cash Dividends at least two years in a row during the study period

- Companies that have a share of ownership by the commissioners and directors for at least two consecutive years during the study period.

A. List of Samples of SOE (Listed) 2010-2018

The list of samples of SOE can be seen in Table 1.

TABLE I. $\quad$ LIST OF SAMPLES OF SOE (LISTED) 2010-2018

\begin{tabular}{|l|l|l|}
\hline NO & \multicolumn{1}{|c|}{ EMITEN } & \multicolumn{1}{|c|}{ CODE } \\
\hline 1 & PT Adhi Karya, Tbk & ADHI \\
\hline 2 & PT Bank Negara Indonesia, Tbk & BBNI \\
\hline 3 & PT Bank Rakyat Indonesia, Tbk & BBRI \\
\hline 4 & PT Bank Mandiri, Tbk & BMRI \\
\hline 5 & PT Kimia Farma, Tbk & KAEF \\
\hline 6 & PT Perusahaan Gas Negara, Tbk & PGAS \\
\hline 7 & PT Semen Gresik, Tbk & SMGR \\
\hline 8 & PT Telekomunikasi Indonesia, Tbk & TLKM \\
\hline 9 & PT Jasa Marga, Tbk & JSMR \\
\hline 10 & PT Wijaya Karya, Tbk & WIKA \\
\hline 11 & PT Bank Tabungan Negara, Tbk & BBTN \\
\hline 12 & PT Pembangunan Perumahan, Tbk & PTPP \\
\hline
\end{tabular}

To test the hypothesis, that Political Connections, Capital Structure, Size, Growth, Profitability have positive effect on Dividend Payout Ratio, regression model is used as follows (See Figure 1):

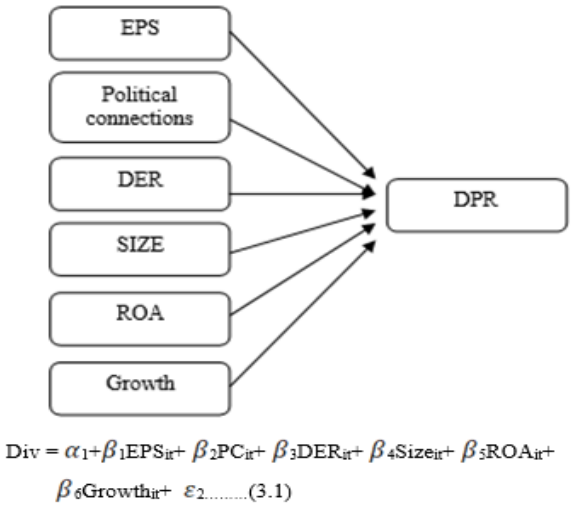

Fig. 1. Regression model. 


\section{RESULTS AND DISCUSSION}

\section{A. Linear Regression Testing}

The linear regression testing can be seen in Table 2 .

TABLE II. LINEAR REGRESSION TESTING

\begin{tabular}{|c|c|c|c|}
\hline Variable & Coefficient & t-Statistic & Prob. \\
\hline C & 0.253446 & 1.352394 & 0.1793 \\
\hline CP & 0.537545 & 1.485765 & 0.1405 \\
\hline DER & -0.001240 & -0.475502 & 0.6355 \\
\hline EPS & -0.589786 & -3.040991 & 0.0030 \\
\hline GROWTH & -0.003996 & -0.867254 & 0.3879 \\
\hline ROA & 2.683424 & 2.949944 & 0.0040 \\
\hline SIZE & 0.014847 & 0.809814 & 0.4200 \\
\hline R-squared & 0.196630 & & \\
\hline
\end{tabular}

This study is to analyses the effect of earnings per share, capital structure, political connections, size, growth, profitability on dividend payments (DPR) in state-owned enterprise (listed) from 2010 to 2018 . The analytical tool used is panel data with the Random Effect Model analysis model and is resolved through computer statistics, namely EViews 9.0. Furthermore, the data processing results presented in this chapter are considered to be the best estimation results because they can meet the criteria of economic theory, statistics and econometrics. The results of this study indicate that political connections have a negative effect on dividend policy with a significance value of 0.1405 . Capital structure has a negative effect on dividend policy with a significance value of 0.6355 . Company size has a positive effect on dividend policy with a significance value of 0.4200 . Growth has a negative effect on dividend policy with a significance value of 0.3879 . Earnings per share has a positive effect on dividend policy with a significance value of 0.0030 . Return on asset has a positive effect on dividend policy with a significance value of 0.0040 . The adjusted R2 value is 0.1966 , so that the variables of political connection, capital structure, earnings per share, company size, company growth and profitability with return on asset are able to influence the dividend policy variable by $19.66 \%$ and the remaining $80,34 \%$ is explained by other factors outside of this research model.

\section{B. Partial Regression Test (t test)}

TABLE III. PARTIAL REgRESSION TEST (T TEST)

\begin{tabular}{|c|c|c|c|}
\hline Variable & Coefficient & t-Statistic & Prob. \\
\hline C & 0.182788 & 0.795024 & 0.4286 \\
\hline CP & 0.665354 & 1.748207 & 0.0837 \\
\hline EPS & -0.580099 & -2.827673 & 0.0057 \\
\hline DER & -0.000307 & -0.107597 & 0.9145 \\
\hline GROWTH & -0.005636 & -1.151834 & 0.2523 \\
\hline ROA & 2.541896 & 2.446685 & 0.0163 \\
\hline SIZE & 0.019937 & 0.875043 & 0.3838 \\
\hline R-squared & \multicolumn{3}{|l}{0.231435} \\
\hline
\end{tabular}

Based on the results in the Table 3, the partial regression test ( $t$ test) shows that the regression coefficient of the Political connections variable is 0.665 with $t$ of 1.748 and a significance of $0.0837>0.05$, this shows that the effect of Political connections on DPR is negative and insignificant. The regression coefficient value of the EPS variable is -0.58 with $t$ of 0.0057 and a significance of $0.0057<0.05$, this shows that the effect of EPS on DPR is negative and significant. The regression coefficient value of the DER variable is -0.0003 with $t$ of 0.91 and a significance of $0.91>0.05$, this shows that the effect of DER on DPR is negative and insignificant. The regression coefficient value of the Growth variable is -0.0056 with $t$ of 0.25 and a significance of $0.25>0.05$, this shows that the effect of Growth on DPR is negative and insignificant. The regression coefficient value of the ROA variable is 2.541 with $t$ of 0.0163 and a significance of $0.0163>0.05$, this shows that the effect of ROA on DPR is positive and insignificant. The regression coefficient value of Size variable is 0.0199 with $t$ of 0.383 and a significance of $0.383>0.05$, this shows that the effect of Size on DPR is positive and insignificant.

\section{Redundant Fixed Effect}

TABLE IV. REDUNDANT FIXED EFFECT

\begin{tabular}{|c|c|c|c|}
\hline Effects Test & Statistic & d.f. & Prob. \\
\hline Cross-section F & 0.526450 & $(8,93)$ & 0.8339 \\
\hline Cross-section Chi-square & 4.783383 & 8 & 0.7805 \\
\hline
\end{tabular}

The results of the redundant fixed effect or likelihood ratio for this model have a probability value of $\mathrm{F}$ of 0.8339 which is greater than alpha 0.05 (See Table 4), so that H0 is accepted and $\mathrm{H} 1$ is rejected, the appropriate model of this result is the common effect.

Researchers hope that in this study the political connections of listed SOEs will have a positive relationship with cash dividend policy. SOE (listed) that have political connections will have more access to resources owned by the government so that it is expected to have higher profitability than companies without political connections. There are advantages that are owned by SOE (listed) companies so that it will give a signal to the market by providing increased dividends.

The size of listed SOE companies in this study has a significant and positive effect on dividends distributed. This shows that the larger the company, the greater the dividends to be distributed. The results of this study are in line with previous studies conducted by Chang and Rhee [17]. SOE (listed) which has a bigger size, the greater the assets owned by the SOE company. The large assets owned by the company will make it easier for the company to enter the capital market and to maintain its reputation in the eyes of its investors, the company will distribute dividends regularly [17].

\section{CONCLUSION}

Based on the results of hypothesis testing, it can be concluded as follows; Earnings per share has a positive effect 
on dividend policy, Political connections have a negative effect on dividend policy, Company size has a positive effect on dividend policy, Growth has a negative effect on dividend policy, Capital structure has a negative effect on dividend policy and last Return on asset has a positive effect on dividend policy.

Some suggestions that can be used for further research are, firstly by adding other factors that come from the aspect of external information to determine dividend distribution policies. Second, to classify companies whose dividend distribution policies have increased and decreased. Third, comparison between state-owned companies and non-stateowned companies in dividend distribution with the same time series.

\section{REFERENCES}

[1] N.D. Rahmawati, I.S. Saerang, and P. Van Rate, "Kinerja Keuangan Pengaruhnya terhadap kebijakan dividen pada perusahaan BUMN di Bursa Efek Indonesia," Jurnal EMBA: Jurnal Riset Ekonomi, Manajemen, Bisnis dan Akuntansi, vol. 2, no. 2, 2014.

[2] R.B.F. Pasaribu, D. Kowanda, and K. Nawawi, "Determinan Dividend Payout Ratio pada Emiten LQ-45 di Bursa Efek Indonesia," Jurnal Ekonomi \& Bisnis, vol. 8, pp. 1-14, 2014.

[3] A. Gupta, and C. Banga, "The Determinants of Corporate Dividend Policy," Decision, vol. 37, no. 2, pp. 63-77, 2010.

[4] A. Gill, N. Biger, and R. Tibrewala, "Determinants of dividend payout ratios: evidence from United States," Open Business Journal, vol. 3, pp. 8-14, 2010.

[5] S. Kapoor, A. Mishra, and K. Anil, "Dividend policy determinants of Indian services sector: a factorial analysis," Paradigm, vol. 14, pp. 2441, 2010.
[6] T. Islam, M. Aamir, A. Ahmad and M. Saeed, "Determinants and Motivators of Dividend Policy: A Study of Cement Industry of Pakistan," Mediterranean Journal of Social Sciences, vol. 3, pp. 103108, 2012.

[7] M. Singhania and A. Gupta, "Determinants of corporate dividend policy: A Tobit model approach," Vision, vol. 16, pp. 153-162, 2012.

[8] F. Malik, S. Gul, M.T. Khan, S.U. Rehman, and M. Khan, "Factors influencing corporate dividend payout decisions of financial and nonfinancial firms," Research Journal of Finance and Accounting, vol. 4, pp. 35-46, 2013.

[9] T. Deitiana, "Faktor-faktor yang mempengaruhi kebijakan pembayaran dividen kas," Jurnal bisnis dan akuntansi, vol. 11, pp. 57-64, 2009.

[10] R.P. Utama, Pengaruh Rasio Keuangan Terhadap Deviden pada Sektor Industri Manufaktur Yang Terdaftar Di Bursa Efek Indonesia tahun 2003-2007. Jakarta: Universitas Gunadarma, 2008.

[11] S. Yudhanto and S. Aisjah, "Pengaruh Net Profit Margin, Return on Asset, Return on Equity, Earning Per Share terhadap Kebijakan Dividen (Studi Pada Perusahaan Manufaktur yang terdaftar di Bursa Efek Indonesia)," Jurnal Ilmiah Mahasiswa FEB, vol. 1, 2012.

[12] H. Zameer, S. Rasool, S. Iqbal, and U. Arshad, "Determinants of dividend policy: A case of banking sector in Pakistan," Middle-East Journal of Scientific Research, vol. 18, pp. 410-424, 2013.

[13] R. Fisman, "Estimating the value of political connections," American Economic Review, vol. 91, pp. 1095-1102, 2001.

[14] S. Johnson and T. Mitton, "Cronyism and capital controls: evidence from Malaysia," Journal of financial economics, vol. 67, pp. 351-382, 2003.

[15] H.K. Baker and G.H. Powell, "Dividend policy issues in regulated and unregulated firms: a managerial perspective," Managerial Finance, vol. 25, pp. 1-20, 1999.

[16] M.A. Roberto, "Making difficult decisions in turbulent times," IVEY business journal, vol. 66, pp. 14-20, 2002.

[17] R.P. Chang and S.G. Rhee, "The impact of personal taxes on corporate dividend policy and capital structure decisions," Financial management, pp. 21-31, 1990. 